\title{
Temperature exposure and possible thermoregulation strategies in the Titicaca water frog Telmatobius culeus, a fully aquatic frog of the High Andes
}

\author{
Arturo Muñoz-Saravia ${ }^{1, *}$, Gabriel Callapa ${ }^{2}$, Geert P. J. Janssens ${ }^{1}$ \\ ${ }^{1}$ Laboratory of Animal Nutrition, Ghent University, 9820 Merelbeke, Belgium \\ ${ }^{2}$ Natural History Museum Alcide d'Orbigny, Cochabamba, Bolivia
}

\begin{abstract}
Temperature has an important effect on amphibians, influencing virtually all physiological systems. Thermoregulation is used to manage unfavourable thermal conditions, but has been poorly studied in aquatic amphibians, and no information is available for adult aquatic anurans. We studied the temperatures to which the Critically Endangered and high Andean fully aquatic Titicaca water frog Telmatobius culeus is exposed and investigated possible thermoregulation strategies of the species in the wild. We measured water temperature in different seasons, microhabitats and depths at which $T$. culeus is most abundant. We established transects to obtain population densities and activity patterns of the species during the day. Seasonal and daily temperature variations as well as temperature variations among depths and microhabitats were noted. These variations were associated with densities of visible $T$. culeus, where adult densities were higher at depths with more stable temperatures. T. culeus behaviour associated with thermoregulation strategies in the aquatic habitat included depth selection and movement of individuals between different microhabitats. Selection of microhabitat depended on the temperature at a site and the hour of the day. These results indicate possible behavioural thermoregulation strategies such as movement to different sites or basking used by a highly specialized amphibian, and provide insights into how aquatic benthic organisms use strategies for thermoregulation in aquatic heterogeneous environments. These strategies are probably also used by other aquatic organisms from the tropical Andes. Knowledge of how these organisms respond to temperature could also help to understand the impact of global warming on their status.
\end{abstract}

KEY WORDS: Endangered amphibian - Lake Titicaca - Temperature - Thermoregulation · Behaviour

\section{INTRODUCTION}

Temperature has a profound effect on biological processes, influencing the physiological performance and fitness of ectotherms (Christian \& Tracy 1981, Hillman et al. 2009, Navas et al. 2013, Basson et al. 2017). An increase or decrease in body temperature can affect different parameters in amphibians such as metabolic rate, feeding, digestion, growth and immunity. These parameters will eventually have an effect on reproduction. In contrast, locomotion in some am-

*Corresponding author: arturo.munozsaravia@ugent.be phibian species is relatively temperature-independent over a narrow range of temperatures (Rome et al. 1992, Rojas et al. 2005, Raffel et al. 2006). Other processes, such as anaerobic metabolism, also undergo very little change with changing temperature (Bennett 1978, Wells 2007). The overall effect of these changes will determine amphibian ecology and eventually the fitness or success of the species and its distribution (Blouin-Demers \& Nadeau 2005, Buckley \& Jetz 2007).

Aquatic amphibians are generally buffered from the extremes of low and high temperatures that ter- 
restrial amphibians can experience (Navas 1997, Hillman et al. 2009), which gives them an advantage in extreme ecosystems such as the highlands. The high heat capacity and thermal diffusivity of water mean that an aquatic amphibian exchanges heat very rapidly with its environment, and so body temperature $\left(T_{\mathrm{b}}\right)$ of the amphibian cannot differ much from the environmental temperature $\left(T_{\mathrm{a}}\right)$ (Hillman et al. 2009, Duarte et al. 2012). In every habitat, temperature varies over time and location according to the balance of energy input and output. The Earth's surface experiences at least 3 temperature cycles at different time scales: daily, annually and infra-annually (Camacho 2012). Aquatic environments tend to be thermally stable over the daily cycle, especially large water bodies, but there are cases where temperatures in shallow, small water bodies and ephemeral ponds can still fluctuate markedly on a daily cycle (Hillman et al. 2009). At high altitudes, heating and cooling cycles can be very fast and the temperature can reach extremely low minimum values (Navas 1997, Wells 2007, Hillman et al. 2009). Such fast cycles decrease the amount of time it takes for the water to change temperature, which tends to have a greater impact on high Andean species (Navas 1997).

To maintain the required temperature for processes such as feeding, digestion, metabolic rate, growth, reproduction and immunity, ectothermic organisms must rely mainly on behavioural adjustments to regulate $T_{\mathrm{b}}$ (Navas 1997). This is particularly the case in amphibians, which have very limited capacity to alter their $T_{\mathrm{b}}$ physiologically (Wells 2007), and especially with small species that have a smaller thermal inertia (Hillman et al. 2009). Aquatic amphibians have limited physiological capacity for thermoregulation because they cannot use strategies such as evaporative water loss to decrease heat, and metabolic processes do not produce enough heat (Wells 2007, Hillman et al. 2009). Behavioural strategies that amphibians use to increase or decrease $T_{\mathrm{b}}$ include heliothermy: getting or gaining heat from the sun (from Greek 'helios' meaning 'sun'); and thigmothermy: getting heat into the body from contact with warm substrates in the environment (from Greek 'thigmo' meaning 'touch') (Wells 2007). As ectotherms, anurans depend primarily on external heat sources to regulate their body temperature. Basking is one of the main mechanisms by which most ectothermic organisms increase body temperature, exposing the whole or a part of the body to direct sunlight (Hillman et al. 2009, Centeno et al. 2015). Especially for amphibians, basking implies water loss through evaporation, and for these species, microhabitat selection with different temperatures is a strategy to maintain desired temperature ranges (Wells 2007). Some aquatic species, such as the mudpuppy salamander Necturus maculosus (Beitinger \& Anderson 1979), can reach their preferred $T_{\mathrm{b}}$ using efficient heat exchange through blood circulation in the gills.

Behavioural thermoregulation has benefits, as it allows an animal to select temperatures that are most favourable (Hillman et al. 2009); however, behavioural thermoregulation also has costs, such as increased exposure to predation, increased energy expenditure and decreased time available for other activities (Wells 2007, Bancroft et al. 2008, Basson et al. 2017).

Information about thermoregulation in adult aquatic amphibians is scarce. Not a single detailed study of thermoregulation in a fully aquatic adult frog has been published, and only a handful of such studies on the thermal ecology of larvae or on salamanders and newts are available (Wilson et al. 2000, Wells 2007, Catenazzi \& Kupferberg 2017). Studying the temperature ranges to which a species is exposed, and identifying the possible behavioural strategies used to maintain its metabolic processes can help to understand how temperature fluctuations in large water bodies in highlands could affect an amphibian species, and to recognize the possible strategies the individuals use to maintain their preferred temperatures using thermoregulation. An understanding of these processes would also help to predict the impact of climate change on the species.

The Titicaca water frog Telmatobius culeus is listed as Critically Endangered (CR) on the IUCN Red List (Icochea et al. 2004). It has also been listed in the Red Book of Bolivian Vertebrates (Aguayo 2009), in De la Riva \& Reichle (2014) and on Peru's Instituto Nacional de Recursos Naturales. In 2017 the species was also included in Appendix I of CITES (CITES 2016). The species is facing a variety of threats such as habitat destruction, overharvesting, introduced exotic species, climate change (Icochea et al. 2004) and emerging infectious diseases such as chytridiomycosis (Catenazzi et al. 2010, Cossel et al. 2014, Berenguel et al. 2016, Zevallos et al. 2016, Burrowes \& De la Riva 2017a,b). T. culeus has experienced serious population declines (Icochea et al. 2004, De la Riva \& Reichle 2014) and in the last few years, local massive die-offs have been reported (BAI 2015, Molina et al. 2017). This frog is endemic to Lake Titicaca and small surrounding lakes (De la Riva 2005) and is considered to be the world's largest fully aquatic frog. The species has unique adaptations such as extremely loose skin, which allows it to breathe underwater without needing to surface for air and is also an adaptation to high altitude (De la Riva 2005, 
De la Riva \& Lavilla 2008). Little information is available about this species, and particularly about the temperature ranges to which it is exposed. General publications about Lake Titicaca indicate that this species lives in cool $\left(10^{\circ} \mathrm{C}\right) \mathrm{O}_{2}$ saturated waters (Hutchison et al. 1976), with superficial temperatures fluctuating between 11.25 and $14.35^{\circ} \mathrm{C}$ (Dejoux 1991, Perez 1998).

We observed differences in the frog's activity depending on the site and time of day, and found them basking on rocks under the water (Fig. 1) in hours with highest solar radiation (see Fig. S1 in the Supplement at www.intres.com/articles/suppl/n037p091_supp .pdf). We thus investigated whether $T$. culeus adapts its behaviour to the temperature, and whether this is possibly

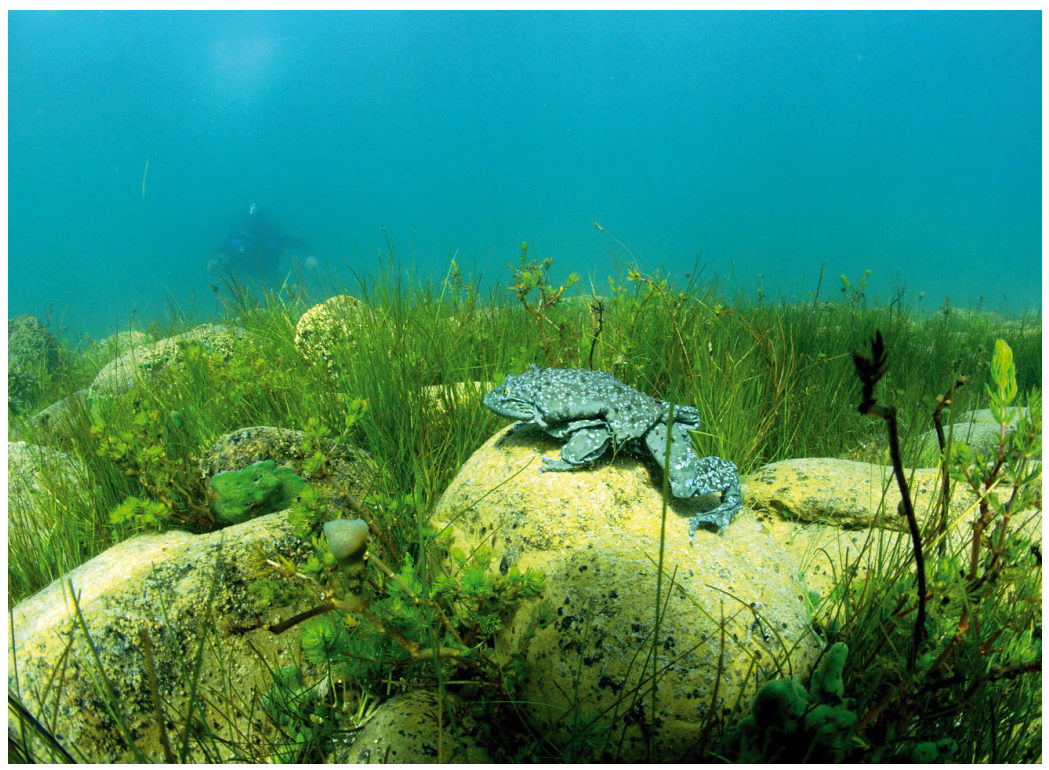

Fig. 1. Female individual of Telmatobius culeus 'basking' on a rock at 14:54 h at a depth of $3 \mathrm{~m}$ at Isla de la Luna, Lake Titicaca, Bolivia (Photo: A. Muñoz) an example of thermoregulatory behaviour of a fully aquatic amphibian living in a lower temperature range. To investigate the temperature to which T. culeus is exposed and determine if the frogs display a thermoregulation strategy, we examined (1) baseline information about seasonal temperature ranges in the habitat of $T$. culeus in one locality of Lake Titicaca, (2) compared the temperature ranges to which different stages of the species are exposed at different depths and microhabitats and (3) identified possible thermoregulation strategies and possible costs-benefits the species faces in these different microhabitats due to potential thermoregulation.

\section{MATERIALS AND METHODS}

\section{Study site}

The study site was adjacent to 'Isla de la Luna' $\left(16^{\circ} 2^{\prime} 42.87^{\prime \prime} \mathrm{S}, 69^{\circ} 4^{\prime} 2.34^{\prime \prime} \mathrm{W}\right)$ in Lake Titicaca, $3810 \mathrm{~m}$ above sea level in the Provincia Manco Kapac of La Paz department, Bolivia (Fig. 2). This site has an average air temperature of 7 to $9^{\circ} \mathrm{C}$ and annual average rainfall of 500 to $1600 \mathrm{~mm}$ (Ibisch \& Mérida 2003), and probably hosts one of the densest populations of Telmatobius culeus. The underwater habitat on the south side of the island, where this study was carried out, includes rocky and sandy areas, in some cases covered by vegetation. All of these substrates were present in combinations, with varying proportions of each substrate. The vegetation of these areas is dom-

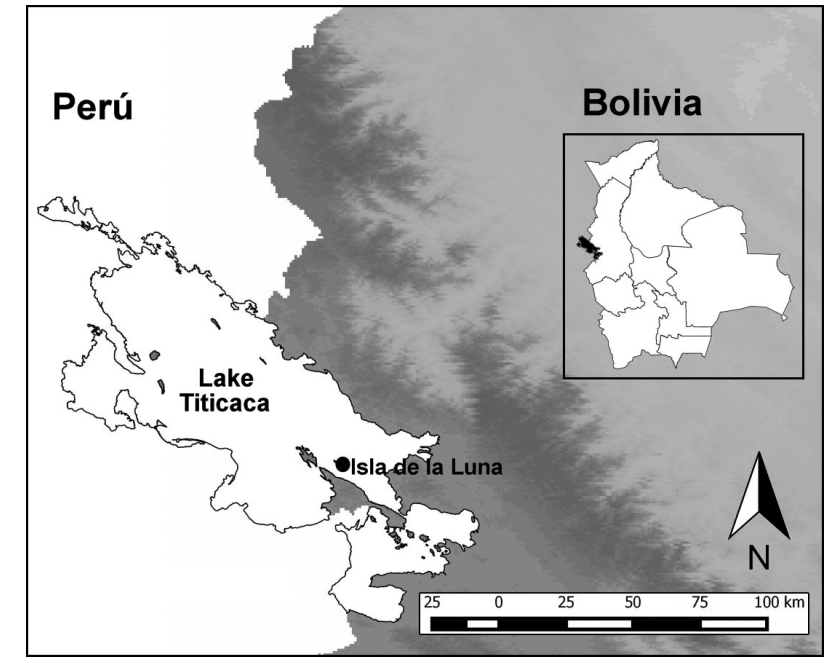

Fig. 2. Study area showing study site, Isla de la Luna, represented by black dot in Lake Titicaca; inset shows location of Lake Titicaca in Bolivia. Map based on CGIAR SRTM (Jarvis et al. 2008) elevation model (light $=$ low, dark = high elevations)

inated by Myriophyllum elatinoides, Elodea potamogeton, Potamogeton spp., Schoenoplectus californium and the cosmopolitan species Zannichellia palustris and Ruppia maritima (Dejoux 1991, Lansdown 2016, GBIF Secretariat 2017). The water contains high levels of dissolved solids, like other areas in the lake, with a pH between 7.55 and 8.15, hardness of 225 to $285 \mathrm{mg} \mathrm{l}^{-1} \mathrm{CaCO}_{3}$, and total alkalinity of 90 to $145 \mathrm{mg}^{-1}$ $\mathrm{CaCO}_{3}$ (Fuentes 2014). 


\section{Temperature measurements}

To measure the temperature range over the year, we used HOBO Water Temperature Pro v2 data loggers (Onset) with an accuracy of $\pm 0.21^{\circ} \mathrm{C}$ and a resolution of $0.02^{\circ} \mathrm{C}$ at $25^{\circ} \mathrm{C}$. A data logger was installed on a rocky area with short vegetation of Zannichellia palustris and Myriophyllum elatinoides for a period of $20 \mathrm{mo}$, at a depth of $2 \mathrm{~m}$ (where most adult frogs are present). This data logger was programmed to measure temperature automatically with intervals ranging from $5 \mathrm{~min}$ to $1 \mathrm{~h}$. Once a month, the data were downloaded to a computer using HOBOware Pro version 3.7.2 software.

To compare temperatures at different depths, we installed the same type of data logger at different depths at the bottom of the lake (Fig. 3). One data logger was positioned outside of the water at ground level to compare aquatic and terrestrial habitats (data logger A); one was placed in the water, under the rocks at a depth of $50 \mathrm{~cm}$ (data logger B); a pair of data loggers were installed together, one on a rock at a depth of $200 \mathrm{~cm}$ (data logger C) and the other under the same rock at $210 \mathrm{~cm}$ (data logger D); and another pair was installed in the same way at a depth of $300 \mathrm{~cm}$ and $310 \mathrm{~cm}$ (data loggers $\mathrm{E}$ and $\mathrm{F}$ respectively). All data loggers above the rocks were attached in a horizontal position directly on rocks of more or less the same size (about $20 \mathrm{~cm}$ diameter), with no shade present for any of the data loggers; all the data loggers under the rocks were under the same rocks used for the data logger above the rocks and these data loggers were not exposed to solar radiation. These data loggers were programmed to measure temperature every $5 \mathrm{~min}$ and measured temperatures for the

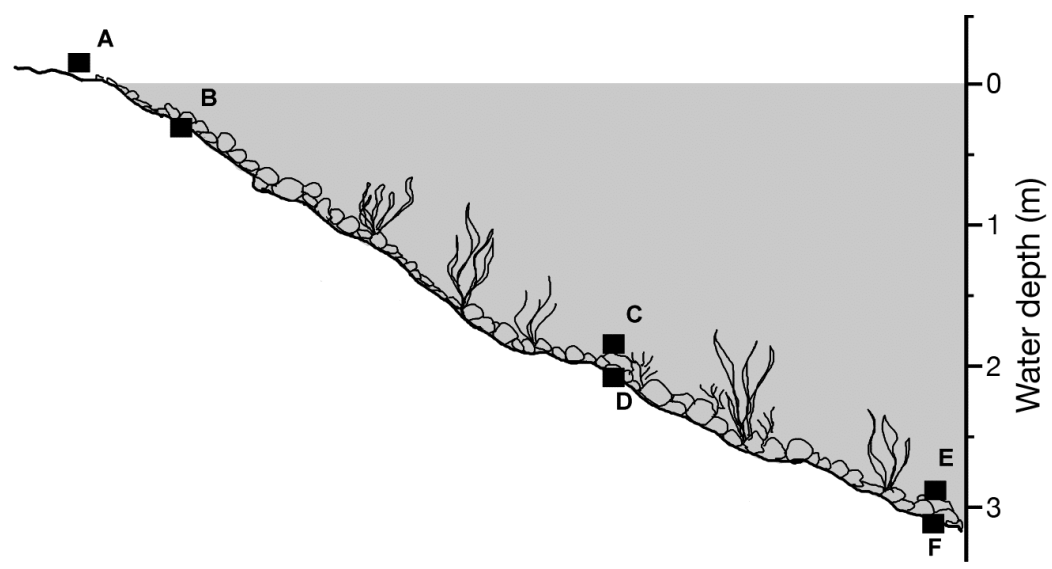

Fig. 3. Profile of the study site, Isla de la Luna, Lake Titicaca, Bolivia. Sites where data loggers were installed represented by black squares. A: outside water (ground level); B: $50 \mathrm{~cm}$ (under rock); C: $200 \mathrm{~cm}$ (on the rock) and D: $210 \mathrm{~cm}$ (under rock); E: $300 \mathrm{~cm}$ (on the rock) and F: $310 \mathrm{~cm}$ (under rock). Grey area: water entirety of 3 consecutive sunny days (2 to 4 December 2015). After this period, data were downloaded using the software HOBOware Pro version 3.7.2. We chose the microhabitats on the rock and under the rock because of the clear variations in densities of basking frogs observed previously. In sandy areas, and in areas with abundant vegetation, logistical issues and low frog densities prevented us from comparing densities within the same site.

\section{Sampling of frogs}

To obtain T. culeus depth and substrate preference in order to correlate them with temperature ranges and possible thermoregulation strategies, we measured the density and activity of the visible frogs at different depths and hours. For the density analysis, we only considered adults, because the presence of juveniles and metamorphs in shallow waters and under the rocks would require other methods that would not allow comparisons. For adults, we carried out transects in Isla de la Luna every month from February 2014 until December 2015, resulting in a total of 22 surveys between 08:00 and 17:00 h. Transects were $100 \mathrm{~m}$ long, divided into sections of $10 \mathrm{~m}$ long and about $4 \mathrm{~m}$ wide. The duration of the surveys was about $30 \mathrm{~min}$ ( $\pm 5 \mathrm{~min}$ ), with variation arising from difficulties experienced in controlling the observer's speed due to wind or water currents. A total of 10 transects of $100 \mathrm{~m}$ were carried out every month. Locations for these transects were chosen randomly within the southeast side of the island covering different habitats and following more or less a parallel line from the shore, trying to cover all depths equally up to $7 \mathrm{~m}$ deep. We snorkelled on the surface of the water, counting all individuals that could be observed at a depth between 0.5 and $7 \mathrm{~m}$. The depth and hour of transect sampling was randomized so that all depths and transects would be sampled at all hours. Transects at these depths were used because previous studies had shown that most frogs occur at depths between 0.5 and $7 \mathrm{~m}$ (A. Muñoz pers. obs.), as also observed by Flores (2013). The species can be found in deeper areas (Perez 1998), but densities are much lower, and safety and logistical considerations prevented systematic SCUBA diving sampling. In most of the transects, the observer also noted behavioural information and breeding activity. 
As well as snorkelling, SCUBA diving observations were carried out, where we randomly turned over rocks on the bottom to get more information regarding individuals possibly present under the rocks, and to note behaviour. These SCUBA diving observations were non-structured transects and were meant to obtain extra information such as presence of individuals of different stages under the rocks, behaviour of frogs at that moment, presence of individuals in amplexus and presence and stage of nests and eggs, among others. We were not able to carry out structured transects because it was difficult to dive for long periods due to altitude and logistical limitations with the diving equipment and staff.

To obtain more information about the depth distribution of $T$. culeus at least down to $7 \mathrm{~m}$, we complemented the transects with quadrats along the shore of the lake, at depths of 0 to $0.5 \mathrm{~m}$, where individuals were counted and captured by hand under the rocks; these data were not used for the density analysis but only to see if frogs were present at these depths, and if so, which age stages.

With captured individuals, the snout-vent length (SVL) and body mass of each individual were measured. Sex was established by the presence of black or brown nuptial pads found only on the thumb of males, present in the breeding season, or white and smaller traces of the nuptial pads found on male frogs when not breeding. The frogs were separated into 2 groups: (1) juveniles: individuals found under rocks in shallow water, sub-adult males with small or absent nuptial pads, and SVL $\leq 51 \mathrm{~mm}$; and (2) adults: found mainly in open water or under rocks in deeper areas, males with nuptial pads or traces of these structures and SVL $>55 \mathrm{~mm}$.

\section{Data analysis}

To compare the temperatures among the different depths and microhabitats (above and under rocks) we conducted 1-way ANOVA analyses using RStudio version 0.98.1087. A post hoc Tukey's honestly significant difference (HSD) test was carried out to determine which depths or microhabitats were significantly different. Comparisons were made for temperatures across the $24 \mathrm{~h}$ period, then for 'cooler' temperatures where solar radiation was absent (between 02:00 and 07:55 h) and finally for 'warm' hours where solar radiation was highest (between 10:00 and 15:55 h).
To determine the relationship between temperature and depth, we used a simple linear regression, with depth as the independent variable and temperature as the dependent variable.

To obtain the density of observed frogs at different hours and depths, we used the number of counted animals per unit area. Density can be estimated using the following equation:

$$
D=n /(2 \times w \times L)
$$

where $D$ is animal density at a given interval of $1 \mathrm{~h}, \mathrm{n}$ is the number of counted animals (abundance), $w$ is effective half width strip of the transect line and $L$ is the length of the transect line (Buckland et al. 2001). We took into account only frogs that were visible during transect sampling, excluding the detection probability (Genova 2011), because we were only interested in the numbers of actively basking frogs on the rocks and exposed sites at that hour or depth. No frogs were counted more than once because they were normally static or moved very short distances, allowing accurate information to be obtained.

To determine if frogs actively moved to microhabitats where temperatures are higher during hours of greater solar radiation (on rocks), we correlated the hour of the day with the temperature and the density of the frogs during this period (presence of frogs on rocks). We also correlated the density of basking frogs (frogs above rocks and exposed sites) at different hours of the day with the mean, maximum and minimum temperatures above the rocks during hours of greater solar radiation.

\section{RESULTS}

\section{Seasonality of temperature}

Average water temperature at Isla de la Luna at a depth of $2 \mathrm{~m}$ during the period studied was $14.24^{\circ} \mathrm{C}$, with a total fluctuation of $6.14^{\circ} \mathrm{C}\left(\min .11 .47^{\circ} \mathrm{C}\right.$ in June 2014, max. $17.61^{\circ} \mathrm{C}$ in December 2014) (Fig. 4). Temperatures showed clear monthly variations, with the warmest months occurring between October and April and the coolest between May and September. We also observed higher temperature variation within months at the end of the cold seasons and beginning of the warm season between September and October ( $\mathrm{SD}=0.62)$ compared to the more stable months of April and June $(\mathrm{SD}=0.35$ ) (see Table $\mathrm{S} 1$ in the Supplement). 


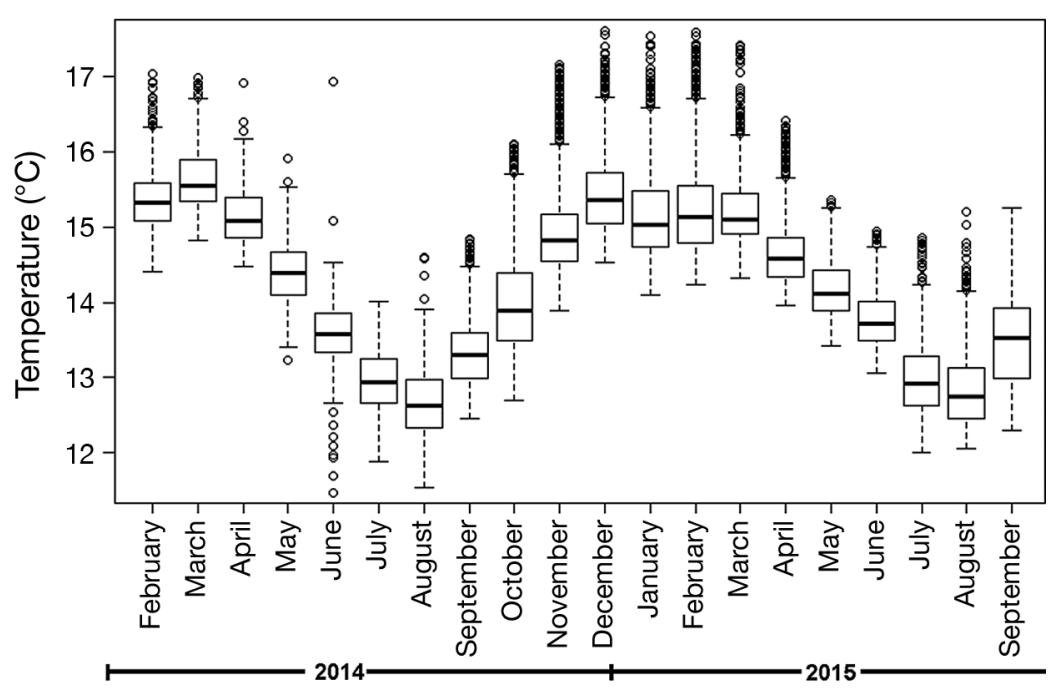

Fig. 4. Monthly temperatures for Isla de la Luna in Lake Titicaca, Bolivia, at $2 \mathrm{~m}$ (data from February 2014 to September 2015). Plots show monthly temperature median (horizontal line), 25th and 75th percentile (box), 5th and 95th percentiles (error bars), and outliers (open circles)

restrial habitat and $0.51^{\circ} \mathrm{C}$ in aquatic habitat). Temperature fluctuation or range differed between the 2 habitats, with a daily variation of $39.50^{\circ} \mathrm{C}$ in terrestrial habitats compared with $3.56^{\circ} \mathrm{C}$ in aquatic habitats (Fig. 5a, Table S2).

\section{Temperatures at different depths and aquatic microhabitats}

Comparing temperatures at different depths above rocks on 3 sunny days (Fig. 5b), there were significant differences (means $\pm \mathrm{SD}$ ) between $2 \mathrm{~m}$ $\left(15.49 \pm 0.58^{\circ} \mathrm{C}\right)$ and $3 \mathrm{~m}(15.35 \pm$ $\left.0.39^{\circ} \mathrm{C}\right)(\mathrm{p} \leq 0.001)$. No difference was found in temperatures under rocks at different depths on the same days $\left(0.5 \mathrm{~m}: 15.24 \pm 0.70^{\circ} \mathrm{C} ; 2.1 \mathrm{~m}: 15.23 \pm\right.$ $0.38^{\circ} \mathrm{C}_{i} 3.1 \mathrm{~m}: 15.23 \pm 0.33^{\circ} \mathrm{C} ; \mathrm{p}=0.99$ ). Average temperatures at the same

\section{Terrestrial versus aquatic temperatures}

Comparison of temperatures outside of the water and at different depths under the water showed that mean temperatures in both habitats were similar (terrestrial habitat: $15.77^{\circ} \mathrm{C}$; aquatic habitat: $15.31^{\circ} \mathrm{C}$ ), although more obvious differences were observed when standard deviations were used $\left(9.40^{\circ} \mathrm{C}\right.$ in ter-
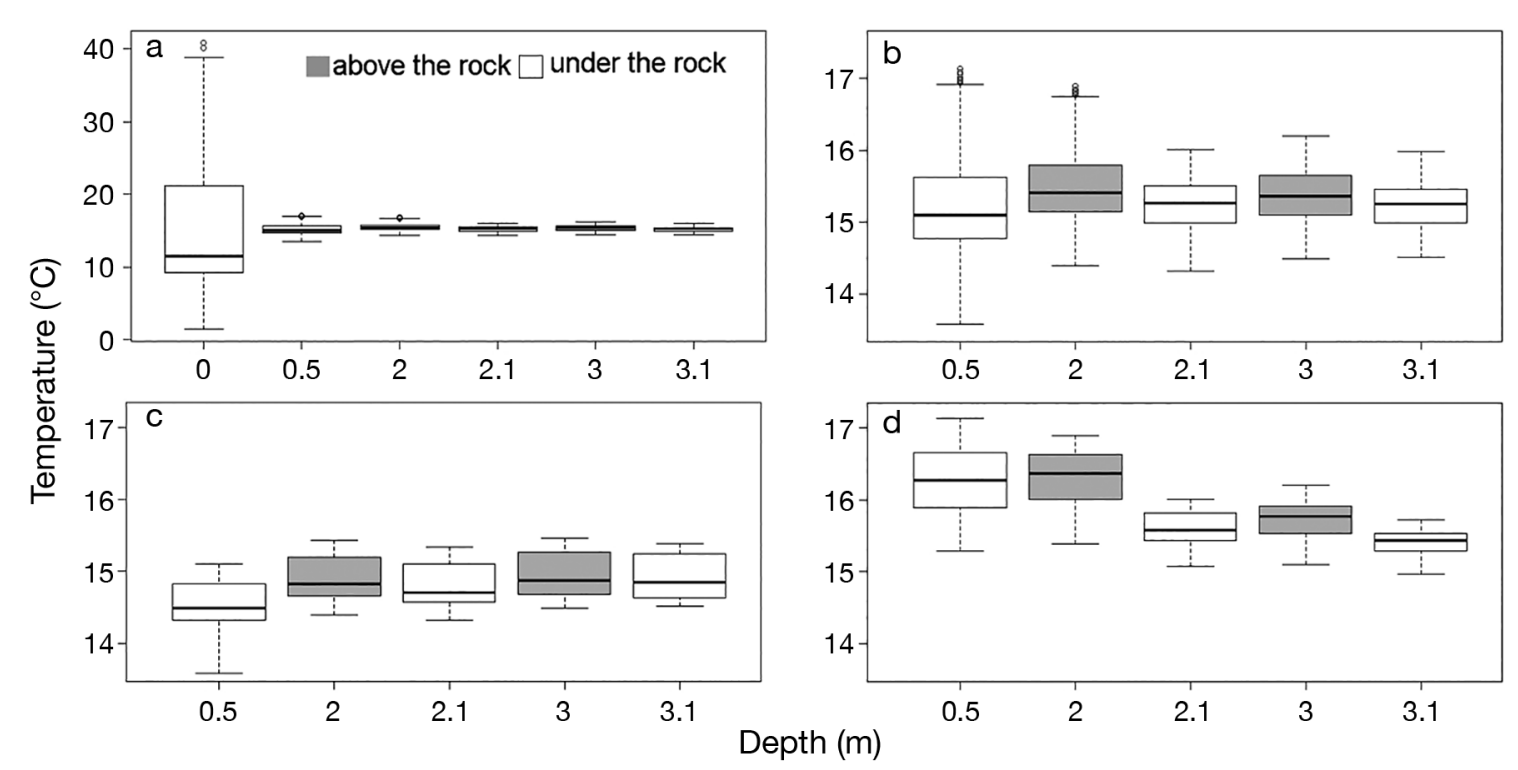
depth but on different substrates (above the rock, exposed to solar radiation, i.e. at 2 or $3 \mathrm{~m}$; and under rocks or surface not exposed to solar radiation, i.e. at 2.1 or $3.1 \mathrm{~m}$ ) were significantly different, being 15.49 $\pm 0.58^{\circ} \mathrm{C}$ and $15.23 \pm 0.38^{\circ} \mathrm{C}$ for 2 and $2.1 \mathrm{~m}$, respectively $(\mathrm{p}<0.001)$ and $15.35 \pm 0.39^{\circ} \mathrm{C}$ and $15.23 \pm$ $0.33^{\circ} \mathrm{C}$ for 3 and $3.1 \mathrm{~m}$, respectively $(\mathrm{p}<0.001)$ (Tables S3 \& S4).

Fig. 5. Temperatures registered in Isla de la Luna in Lake Titicaca, Bolivia, in December 2015. (a) All temperatures outside water (ground level, on the beach of the lake) and underwater; (b) all temperatures underwater over $24 \mathrm{~h}$ throughout the study period (showing data for 0.5 to $3.1 \mathrm{~m}$ depth from (a) in more detail); (c) temperatures at cold hours underwater (02:00 to 08:00 h); (d) temperatures at hours with high solar radiation underwater (10:00 to 16:00 h). Depths correspond to data loggers: 0: data logger $A_{;}$0.5: data logger $B_{;} 2$ : data logger $C ; 2.1$ : data logger $D_{;} 3$ : data logger $E_{;} 3.1$ : data logger F. Box plots as in Fig. 4 
Between 02:00 and 07:55 h, when air temperatures were lower and no solar radiation was present (Fig. 5c), shallower waters were generally colder than deeper areas. At $2 \mathrm{~m}$, temperatures above rocks were no different $\left(14.89 \pm 0.29^{\circ} \mathrm{C}\right)$ than at $3 \mathrm{~m}\left(14.94 \pm 0.30^{\circ} \mathrm{C}\right)$ $(\mathrm{p}=0.62)$, whereas temperatures under rocks differed among all depths $\left(0.5 \mathrm{~m}: 14.53 \pm 0.31^{\circ} \mathrm{C} ; 2.1 \mathrm{~m}\right.$ : $\left.14.81 \pm 0.29^{\circ} \mathrm{C}_{i} 3.1 \mathrm{~m}: 14.91 \pm 0.29^{\circ} \mathrm{C}_{i} \mathrm{p}<0.05\right)$. Temperatures above and under rocks at the same depth were not significantly different, being $14.90 \pm 0.29^{\circ} \mathrm{C}$ and $14.81 \pm 0.29^{\circ} \mathrm{C}(\mathrm{p}=0.07)$ for 2 and $2.1 \mathrm{~m}$, respectively; and $14.95 \pm 0.30^{\circ} \mathrm{C}$ and $14.91 \pm 0.29^{\circ} \mathrm{C}(\mathrm{p}=0.8)$ for 3 and $3.1 \mathrm{~m}$, respectively (Tables S5 \& S6).

Between 10:00 and 15:55 h, when solar radiation was higher (Fig. 5d), temperatures on rocks were higher at $2 \mathrm{~m}\left(16.31 \pm 0.38^{\circ} \mathrm{C}\right)$ than at $3 \mathrm{~m}(15.72 \pm$ $\left.0.28^{\circ} \mathrm{C}\right)(\mathrm{p}<0.001)$. Findings were similar for temperatures under rocks $\left(0.5 \mathrm{~m}: 16.27 \pm 0.47^{\circ} \mathrm{C} ; 2.1 \mathrm{~m}: 15.59 \pm\right.$ $\left.0.24^{\circ} \mathrm{C}_{i} 3.1 \mathrm{~m}: 15.40 \pm 0.20^{\circ} \mathrm{C}_{i} \mathrm{p}<0.001\right)$. Temperatures above and under rocks during hours of more radiation showed greater differences than during hours of no solar radiation or over a $24 \mathrm{~h}$ period. Finally, temperatures at 2 and $2.1 \mathrm{~m}\left(16.31 \pm 0.38^{\circ} \mathrm{C}\right.$ and $15.59 \pm 0.24^{\circ} \mathrm{C}$, respectively) showed a larger difference than temperatures at 3 and $3.1 \mathrm{~m}\left(15.72 \pm 0.28^{\circ} \mathrm{C}\right.$ and $15.40 \pm$ $0.20^{\circ} \mathrm{C}$, respectively) ( $\left.\mathrm{p}<0.001\right)$ (Tables S7 \& S8).

\section{Temperature fluctuations in water correlated with depth}

When comparing the fluctuation in temperature at different depths on 3 consecutive sunny days in the hottest month, we noticed that shallower waters were exposed to more extreme changes in temperature than deeper waters. A negative correlation $(F=12.84$, $\mathrm{R}^{2}=0.81, \mathrm{p}=0.37$ ) between standard deviation and

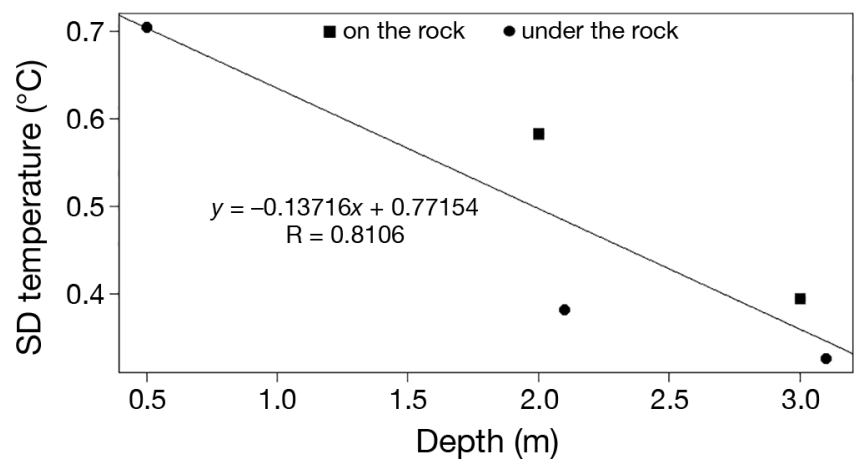

Fig. 6. Standard deviation of temperatures registered at different depths and underwater microhabitats at Isla de la Luna in Lake Titicaca, Bolivia, during 24 h over $3 \mathrm{~d}$ in December 2015 depth was revealed, with deeper waters having less temperature variation than shallow waters (Fig. 6): shallower water had a temperature fluctuation of $3.56 \pm 0.70^{\circ} \mathrm{C}$ whereas deeper waters $(3 \mathrm{~m})$ had a range of $1.48 \pm 0.32^{\circ} \mathrm{C}$.

Temperature variation also differed between microhabitats at the same depth. At $2 \mathrm{~m}$, variability was higher on rocks $\left(2 \mathrm{~m} ; \mathrm{SD}=0.38^{\circ} \mathrm{C}\right)$ than under rocks $\left(2.1 \mathrm{~m} ; \mathrm{SD}=0.24^{\circ} \mathrm{C}\right)$; during hours of more radiation, the difference in temperature between these 2 microhabitats was $1.12^{\circ} \mathrm{C}$. At $3 \mathrm{~m}$, the temperature difference was smaller $\left(0.60^{\circ} \mathrm{C}\right)$, with a larger standard deviation on rocks $\left(3 \mathrm{~m} ; \mathrm{SD}=0.29^{\circ} \mathrm{C}\right)$ than under rocks $\left(3.1 \mathrm{~m} ; \mathrm{SD}=0.20^{\circ} \mathrm{C}\right.$ ) (see Figs. S2 \& S3).

\section{Depth preference of Telmatobius culeus}

The transect observations showed that adults mainly used depths between 1.5 and $3 \mathrm{~m}$, with higher densities of basking frogs at $1.5 \mathrm{~m}: 28 \%(D=0.28$ ind. $\left.\mathrm{m}^{-2}\right) ; 2 \mathrm{~m}: 23 \%\left(D=0.23\right.$ ind. $\left.\mathrm{m}^{-2}\right) ; 2.5 \mathrm{~m}: 17 \%(D=$ 0.17 ind. $\left.\mathrm{m}^{-2}\right)$; and $3 \mathrm{~m}: 12 \%\left(D=0.12\right.$ ind. $\left.\mathrm{m}^{-2}\right)$ of observed individuals. Other depths each accounted for $<10 \%$ of the observations (Fig. 7). We also observed that all breeding individuals and those with eggs were at depths between 1.5 and $3 \mathrm{~m}$. Other age stages, such as metamorphs and juveniles, were found in shallow waters $\leq 0.5 \mathrm{~m}$, but never in deeper waters. No larvae were found in the snorkelling transects during this period; only 5 larvae in Gosner stage 25 to 26 were found during SCUBA diving, but all of

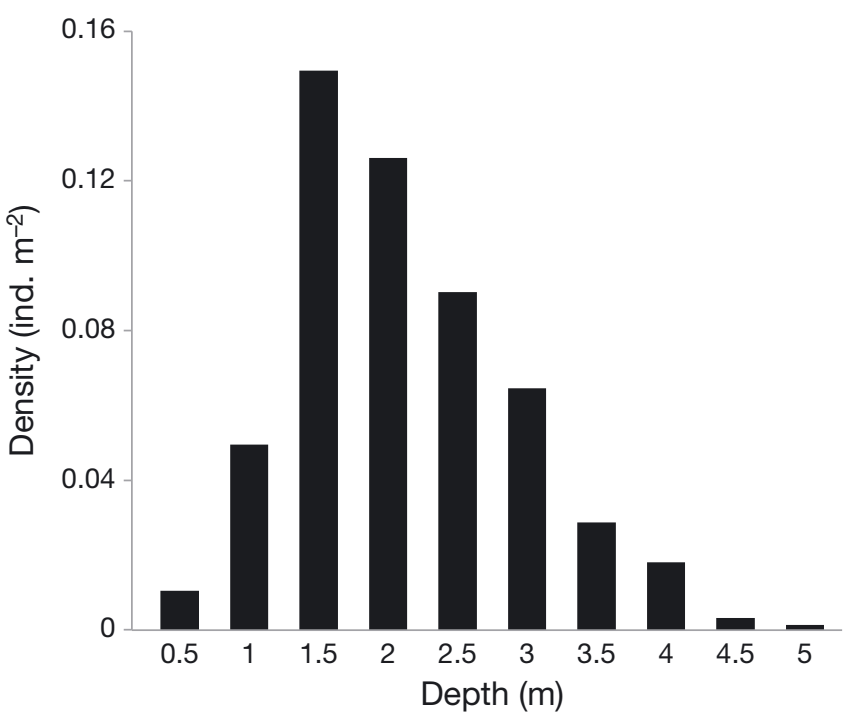

Fig. 7. Densities of individuals of Telmatobius culeus observed during transects at different depths at Isla de la Luna in Lake Titicaca, Bolivia, from February 2014 until December 2015 
them were in poor body condition and were swimming erratically in the water column.

\section{Daytime microhabitat preference of $T$. culeus}

The number of individuals observed along transects changed throughout the day, with a clear increase in numbers of frogs during hours with more solar radiation (Fig. S6). During the day, most individuals $(77.6 \%)$ were found between $11: 00$ and

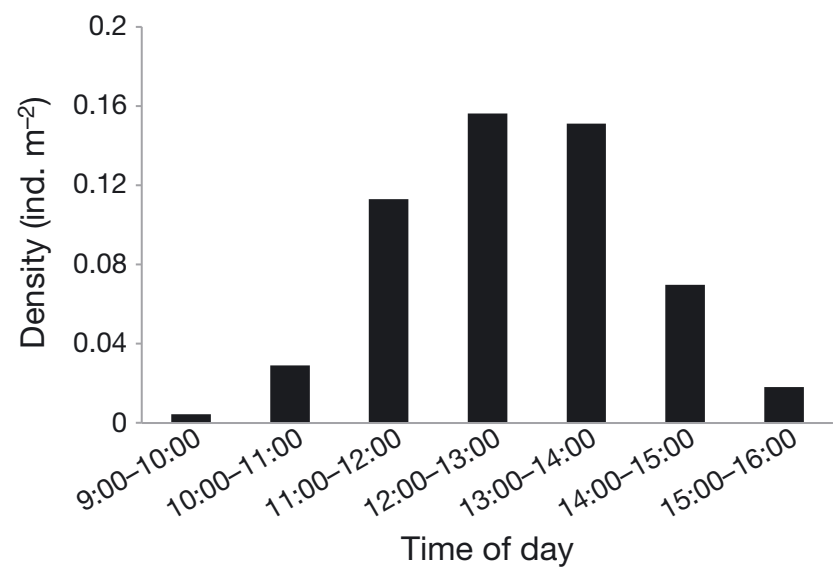

Fig. 8. Densities of individuals of Telmatobius culeus observed during transects at depths of 0.5 to $2.5 \mathrm{~m}$ at different hours at Isla de la Luna in Lake Titicaca, Bolivia, from February 2014 until December 2015
14:00 $\mathrm{h}$ above rocks or exposed sites (Fig. 8). Frogs that were found on rocks were always adults that were basking on exposed sites and, when disturbed, escaped to hide in more protected places (Figs. S3S5). No juveniles were found basking during this study.

During the warmer months (November to March), densities of observed frogs (Fig. 9) at the beginning of the day (08:00 to 09:00 h) were relatively low (0.04 to 0.08 ind $\mathrm{m}^{-2}$ ), increasing between 10:00 and 12:00 h ( 0.13 to 0.22 ind $\mathrm{m}^{-2}$ ) above rocks when temperatures at these sites increased. Frog densities above rocks decreased between 13:00 and 15:00 h (0.17 to 0.08 ind. $\mathrm{m}^{-2}$ ), probably because individuals hid under the rocks. All months except March showed the same pattern: in March, frog numbers increased slowly and started to decrease from 14:00 h (Fig. 9).

Correlating temperatures with this relationship (Fig. 10), we found that densities of frogs above rocks started to increase during hours with more solar radiation (11:00 to 14:00 h), which were also the hours when temperatures above rocks were higher than temperatures under the rocks (Fig. 5d). From 13:00 h on, the numbers of frogs start to decrease.

\section{DISCUSSION}

Based on our data, Telmatobius culeus in Isla de la Luna occurs at water temperatures around $14^{\circ} \mathrm{C}$ with
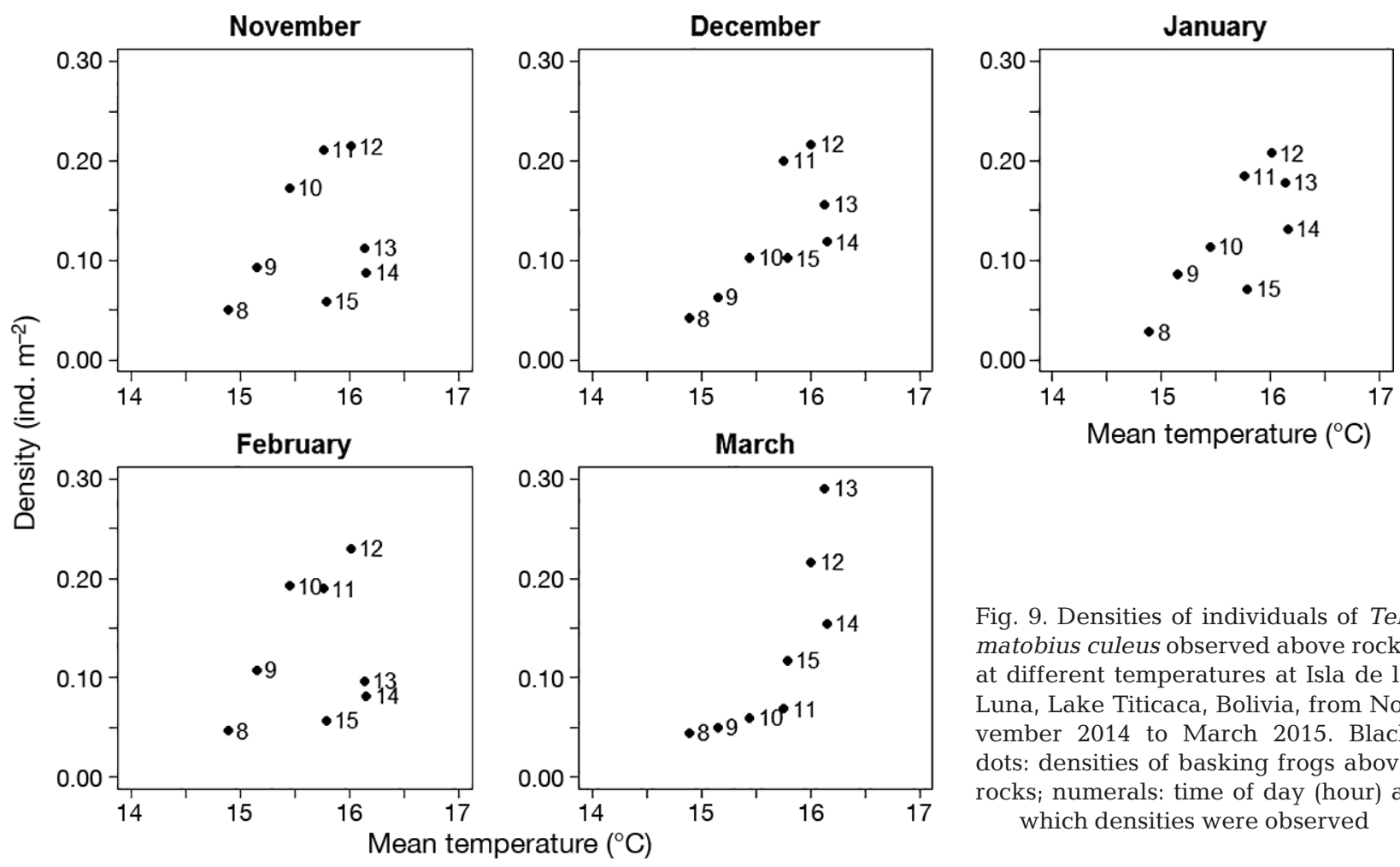

Fig. 9. Densities of individuals of Telmatobius culeus observed above rocks at different temperatures at Isla de la Luna, Lake Titicaca, Bolivia, from November 2014 to March 2015. Black dots: densities of basking frogs above rocks; numerals: time of day (hour) at which densities were observed 

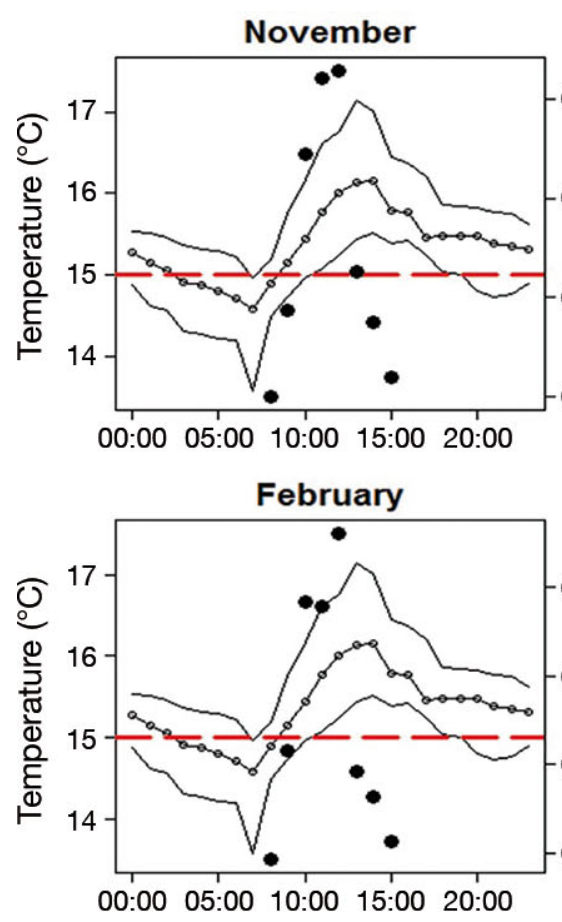
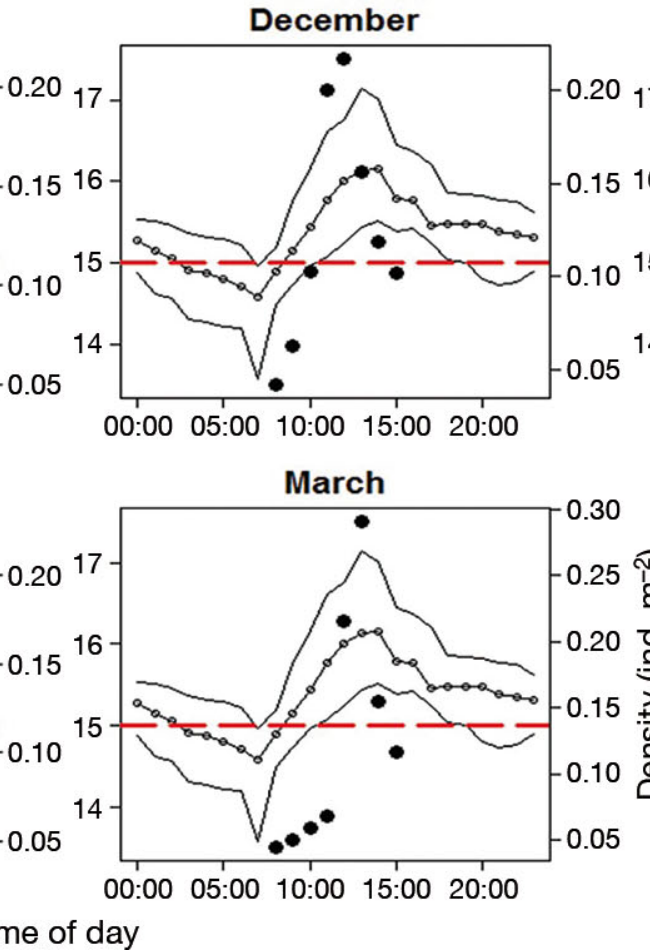
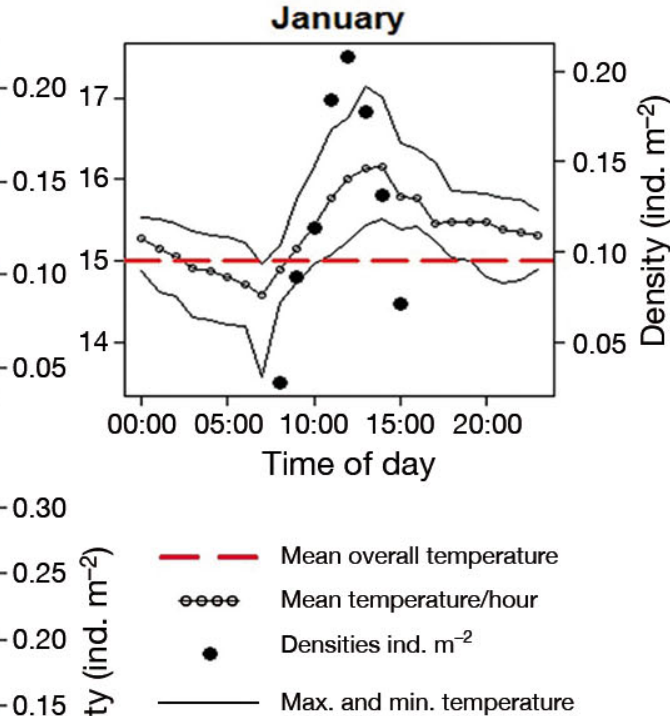

Fig. 10. Water temperatures at different hours of the day and densities of basking individuals of Telmatobius culeus above the rocks in Isla de la Luna, Lake Titicaca, Bolivia, from November 2014 to March 2015

a fluctuation of approximately $6^{\circ} \mathrm{C}$. In contrast, temperature variation in the terrestrial habitat at Isla de la Luna (3810 $\mathrm{m}$ a.s.l.) was very high, with a daily fluctuation of $39.5^{\circ} \mathrm{C}$. These large daily thermal ranges, which are normal for high neotropical Andean anurans inhabiting elevations >3000 m (Navas 1997, Wells 2007), cause terrestrial species to choose more stable microhabitats. For example, Microkayla illimani (3680 $\mathrm{m}$ a.s.l.) breeds and lays eggs in humid places under rocks or moss, where offspring experience daily temperature fluctuations of $18.7^{\circ} \mathrm{C}$ over period of $28 \mathrm{~d}$ (Willaert et al. 2016). By inhabiting the milder aquatic environments in the Andes, anuran species such as $T$. culeus can be active and breed throughout almost the entire year, as indicated by Perez (1998) and Brunetti et al. (2017). In addition, the depths at which T. culeus adults are most abundant provide access to better sources of nutrients than shallow waters, including small fish of the genus Orestias, which provide higher levels of proteins and lipids than the snails and small amphipods of the genus Hyalella that are more abundant in shallow waters (A. Muñoz pers. obs.).

It is important to note that the average water temperature and variation in temperature identified in the present study differ from those reported in earlier studies. Navas (1997), Hutchison et al. (1976) and Hutchison (1982) indicated that T. culeus was exposed to water temperatures ranging from 8 to $12.5^{\circ} \mathrm{C}$, with Hutchison et al. (1976) showing that surface waters averaged $10^{\circ} \mathrm{C}$ with $\mathrm{a}<4^{\circ} \mathrm{C}$ annual range. However, we found that temperatures at the depths at which T. culeus was most abundant (between 1.5 and $3 \mathrm{~m}$ ) were not homogenous throughout the day, with a daily fluctuation of $>3^{\circ} \mathrm{C}$, and we identified a variation in temperature between depths of 0 and $3 \mathrm{~m}$. This provides $T$. culeus with a variety of thermal microhabitats. In addition, temperature variations among microhabitats were identified, with average temperatures under and above rocks being different when solar radiation was high. However, the temperature extremes showed clear variation among habitats, and could play a more important role than average temperatures (Camacho et al. 2015).

Although the observed water temperature variations appear relatively small, it is known that the heat capacity of water is approximately 3000 times greater than that of air; even in still water, heat is dissipated as rapidly as it reaches the surface from the body core (Erskine \& Spotila 1977). Thus, small temperature differences can have a disproportionate impact on physiological functions, making a slightly warmer site potentially more beneficial for certain metabolic and physiological processes. Aquatic amphibians exchange heat with the environment through blood vessels just beneath the skin (Beitinger \& Anderson 1979). T. culeus has high levels of blood vessels and 
cutaneous capillaries that penetrate the outer layers of the skin (Hutchison et al. 1976). We postulate that this species is likely to use this strategy not only to obtain oxygen, but also to regulate temperature and absorb heat from rocks.

We postulate that the availability of a range of temperature zones promotes better physiological performance. Thermoregulation strategies are used by different amphibian species to maintain temperatures that allow optimal performance, and some amphibian species use mainly behavioural thermoregulation strategies such as heliothermy or thigmothermy by moving from one site to another with different temperatures (Hillman et al. 2009). However, balancing the positive and negative effects of temperature is important for amphibians, and this is probably also the case for T. culeus. For example, it is proposed that some amphibian communities (e.g. tropical montane salamanders with narrow distributions) are at risk of extinction (Wake \& Vredenburg 2008), due in part to warming-induced physiological depression (Bernardo \& Spotila 2006, Duarte et al. 2012).

Adult T. culeus are most abundant at depths of 1.5 to $3 \mathrm{~m}$, where water temperature is relatively stable but temperature differences between microhabitats related to rocks provide opportunities for frogs to bask in warmer and exposed places (above rocks). In shallow waters, daily temperature variations are much larger. Juveniles of $T$. culeus are abundant in this environment and therefore are likely to experience greater thermal variation than adults. The degree to which a given species engages in active thermoregulation represents a balance between costs and benefits (Huey \& Slatkin 1976, Huey 1982). When the environment imposes a high energetic cost, animals should thermoconform rather than thermoregulate (Basson et al. 2017); T. culeus juveniles may experience greater thermal variation than adults, but being under rocks in shallower waters, may be under lower pressure from predators that exist in deeper water such as fish (e.g. Oncorhynchus mykiss and Odontesthes bonariensis), birds (e.g. Phalacrocorax brasilianus) and even conspecifics that can depredate smaller individuals (A. Muñoz pers. obs.). Predation pressure exists in shallow waters from birds such as Larus serranus and Nycticorax nycticorax, but only if juveniles are active above rocks (A. Muñoz pers. obs.). For this reason, T. culeus juveniles probably stay under rocks for safety and are possibly more thermoconformist. Such a shift in behaviour or microhabitat use has been observed in other amphibian species such as the cane toad Rhinella marina (Pizzatto et al. 2008).
With respect to the embryonic stage, it is known that some species of Telmatobius, such as T. laticeps, T. pisanoi and T. oxycephalus, lay eggs under rocks to avoid predation (Lavilla \& Barrionuevo 2005, A. Brunetti pers. comm.). Eggs of T. culeus were found in exposed sites close to areas in which the adults bask and at similar temperatures. This is probably a strategy to benefit from slightly higher temperatures that help in the development and hatching of their eggs. The adults' metabolism may also benefit from these sites; the increased risk of predation would then be compensated by parental care from the male (Brunetti et al. 2017).

Although anuran thermal physiology is phenotypically plastic and susceptible to adaptive evolution (Navas et al. 2008), it is not clear how temperatures and temperature fluctuations affect adults and juveniles, and how these frogs could be adapted to daily temperature changes. According to Wells (2007) and Hillman et al. (2009), no detailed study of thermoregulation in adult fully aquatic frogs is available.

The body temperature of amphibians dictates their metabolic activity, with higher metabolic rates at higher temperatures (Homyack et al. 2010, Kristín \& Gvoždík 2014). With any event that creates a situation in which not all necessary thermal zones are available, the frog will no longer be able to display adequate thermoregulatory behaviour. In fish, even mild increases in water temperature can stimulate greater protein catabolism (Geda et al. 2012), which generally leads to decreased energetic efficiency. In the case of T. culeus, which has one of the lowest metabolic rates among amphibians (Hutchison 1982) and is fully aquatic, these apparently small temperature differences between microhabitats, and larger temperature variations between depths, could modulate their metabolic rate and protein catabolism. This in turn could affect body condition. As Geda et al. (2012) indicated, the combination of increased metabolic rate and decreased assimilation efficiency will lead to loss of body condition, which can be aggravated by the lack of specific nutrients derived from prey that are no longer available due to the shift in temperature. Poor body condition has been related to poor reproductive performance (Litzgus et al. 2008, Barnett et al. 2015). Thus, indirectly, the inability to adequately thermoregulate puts pressure on the population through body condition loss, and a higher sensitivity to disease is likely to compound the negative effects of restricted thermoregulatory behaviour (Barnett et al. 2015). Temperature effects on immunity have been described in newts (Raffel et al. 2006) and leopard frogs (Maniero \& Carey 1997), and increased susceptibility 
due to temperature changes has been implicated in outbreaks of the amphibian disease chytridiomycosis, with higher mortality at temperatures $\left(17\right.$ to $\left.25^{\circ} \mathrm{C}\right)$ that provide better conditions for the reproduction and spread of Batrachochytrium dendrobatidis $(B d)$ (Berger et al. 2004, Andre et al. 2008). Bd has been present in the lake for many decades (Burrowes \& De la Riva 2017a) and have been found in different places in the Bolivian and Peruvian Andes (Burrowes \& De la Riva 2017a,b, Catenazzi et al. 2017, Seimon et al. 2017). It seems T. culeus is not strongly affected. If, however, temperatures increase due to climate change, this would not just affect the metabolic rate or body condition of this population, but would also expose the species to higher temperatures than the average of $15^{\circ} \mathrm{C}$ recorded in this study. In these new temperature ranges, $B d$ could be more virulent, and thus this shift in temperature could make the frog more susceptible to this disease.

Laboratory studies would also need to take into account whether factors other than temperature could influence frog behaviour. For example, exposure to UV radiation could explain basking behaviour, because it is known that UV light is important for the synthesis of vitamin D3, as an intermediate step in the absorption of calcium (Wright \& Whitaker 2001). Thus, absorption and scattering of UV light in the water column should be taken into account, to determine whether UV-B radiation penetrates to the depths where frogs are basking during the hours when this behaviour occurs. Sommaruga \& Psenner (1997) reported a $10 \%$ attenuation of UV light at $9.6 \mathrm{~m}$ depth at the wavelengths of $305 \mathrm{~nm}$ in an oligotrophic Austrian lake located at 2417 a.s.l., but also reported changing values depending of the water transparency. The wavelengths between 290 and $315 \mathrm{~nm}$ are where vitamin D3 is synthetized (MacLaughlin et al. 1982), so we assume that $T$. culeus probably receives some UV radiation in shallow water. Häder et al. (2015) provided a complete review on the effects of UV radiation on aquatic ecosystems but little information was provided for aquatic amphibians. Potential prey items are mainly under the rocks during the hours in which basking behaviour is mainly observed, with the exception of snails, which are present in these microhabitats at all times. This suggests that access to food is not a reason why frogs are on the rocks at these hours.

Although we present information from just one location, these patterns can likely be extrapolated to other localities within the same depths in the large, more northerly part of the lake (Lago Mayor). The situation is slightly different in the small, more southerly part of the lake (Lago Menor) where temperatures are, on average, higher and more variable (A. Muñoz pers. obs.). This could provide an opportunity to study the effects of global warming where an aquatic species is exposed to different temperature ranges, because shallower waters are likely to be the first to be impacted by global warming.

Information on the seasonal and daily temperature regime to which $T$. culeus is exposed has been and will be very useful for captive breeding programs. For example, the captive breeding program for the species in Bolivia started to have success with breeding the species when they simulated the seasonal temperature changes observed in the lake, suggesting that temperature change might be a trigger for reproduction in this species (Bolivian Amphibian Initiative pers. comm.). The same situation was observed in the captive breeding program in Denver Zoo in the USA (T. J. Weaver pers. comm.).

In conclusion, this study shows that $T$. culeus is exposed to both temporal and local temperature variations, and proposes that thermal zone preference and basking behaviour are 2 main strategies the species uses for thermoregulation. These findings warrant laboratory studies on temperature preference, tolerance and the effect of temperature on frog physiology. If pollution and global warming events reduce the ability of $T$. culeus to display thermoregulatory behaviour, this may negatively affect the population of this endangered species.

Acknowledgements. We thank the Dirección General de Biodiversidad for providing permission to undertake this study under the Bolivian amphibian project (VMABCC\#0919/11), the Museo de Historia Natural Alcide d'Orbigny for its support during this project, and all the members and volunteers working in the Bolivian Amphibian Initiative. A.M.S. was supported by BOF UGent, and fieldwork was supported by Rufford Small Grants, SOS Save our Species, Stiftung Artenschutz, Amphibian Ark, Durrell Wildlife Conservation Trust and Denver Zoo. Special thanks to the local community of Isla de la Luna for allowing us to study in the area and helping us during the fieldwork. A.M.S. thanks Andrew D. Noble for valuable comments and English improvement. None of the authors have a conflict of interest to declare.

\section{LITERATURE CITED}

Aguayo R (2009) Capitulo 3: anfibios. In: Aguirre LF, Aguayo R, Balderrama JA, Claudia Cortez F, Tarifa T, Rocha O (eds) Libro Rojo de la fauna silvestre de vertebrados de Bolivia. Ministerio de Medio Ambiente y Agua, La Paz, p 91-224

Andre SE, Parker J, Briggs CJ (2008) Effect of temperature on host response to Batrachochytrium dendrobatidis 
infection in the mountain yellow-legged frog (Rana muscosa). J Wildl Dis 44:716-720

BAI (Bolivian Amphibian Initiative) (2015) Bolivian Amphibian Initiative. http://bolivianamphibianinitiative.org/ titicaca-water-frog-project/ (accessed 15 Jan 2018)

Bancroft BA, Baker NJ, Searle CL, Garcia TS, Blaustein AR (2008) Larval amphibians seek warm temperatures and do not avoid harmful UVB radiation. Behav Ecol 19:879-886

Barnett CA, Suzuki TN, Sakaluk SK, Thompson CF (2015) Mass-based condition measures and their relationship with fitness: In what condition is condition? J Zool (Lond) 296:1-5

Basson CH, Levy O, Angilletta MJ, Clusella-Trullas S (2017) Lizards paid a greater opportunity cost to thermoregulate in a less heterogeneous environment. Funct Ecol 31: 856-865

Beitinger TL, Anderson K (1979) Internal convective and conductive heat loss in the mudpuppy, Necturus maculosus. Comp Biochem Physiol Part A Physiol 62:1035-1039

Bennett AF (1978) Activity metabolism of the lower vertebrates. Annu Rev Physiol 40:447-469

* Berenguel RA, Elias RK, Weaver TJ, Reading RP (2016) Chytrid fungus, Batrachochytrium dendrobatidis, in wild populations of the Lake Titicaca frog, Telmatobius culeus, in Peru. J Wildl Dis 52:973-975

Berger L, Spear R, Hines HB, Marantelli G and others (2004) Effect of season and temperature on mortality in amphibians due to chytridiomycosis. Aust Vet J 82:434-439

Bernardo J, Spotila JR (2006) Physiological constraints on organismal response to global warming: mechanistic insights from clinally varying populations and implications for assessing endangerment. Biol Lett 2:135-139

Blouin-Demers G, Nadeau P (2005) The cost-benefit model of thermoregulation does not predict lizard thermoregulatory behavior. Ecology 86:560-566

Brunetti AE, Muñoz-Saravia A, Barrionuevo JS, Reichle S (2017) Silent sounds in the Andes: underwater vocalizations of three frog species with reduced tympanic middle ears. Can J Zool 95:335-343

Buckland ST, Anderson DR, Burnham KP, Laake JL, Borchers DL, Thomas L (2001) Introduction to distance sampling, estimating abundance of biological populations. Oxford University Press, Oxford

Buckley LB, Jetz W (2007) Environmental and historical constraints on global patterns of amphibian richness. Proc $\mathrm{R}$ Soc B 274:1167-1173

Burrowes PA, De la Riva I (2017a) Detection of the amphibian chytrid fungus Batrachochytrium dendrobatidis in museum specimens of Andean aquatic birds: implications for pathogen dispersal. J Wildl Dis 53:349-355

Burrowes PA, De la Riva I (2017b) Unravelling the historical prevalence of the invasive chytrid fungus in the Bolivian Andes: implications in recent amphibian declines. Biol Invasions 19:1781-1794

Camacho A (2012) Respostas dos animais ectotermos terrestres à variação microclimática. Rev Biol 8:5-14 doi: 10.7594/revbio.08.02

Camacho A, Rodrigues MT, Navas C (2015) Extreme operative temperatures are better descriptors of the thermal environment than mean temperatures. J Therm Biol 4950:106-111

Catenazzi A, Vredenburg VT, Lehr E (2010) Batrachochytrium dendrobatidis in the live frog trade of Telmatobius (Anura: Ceratophryidae) in the tropical Andes. Dis Aquat Org 92:187-191
Catenazzi A, Kupferberg SJ (2017) Variation in thermal niche of a declining river-breeding frog: from individual counter-gradient responses to population distribution patterns. Freshw Biol 62:1255-1265

Catenazzi A, Swei A, Finkle J, Foreyt E, Wyman L, Vredenburg VT (2017) Epizootic to enzootic transition of a fungal disease in tropical Andean frogs: Are surviving species still susceptible? PLOS ONE 12:e0186478

* Centeno FC, Antoniazzi MM, Andrade DV, Kodama RT, Sciani JM, Pimenta DC, Jared C (2015) Anuran skin and basking behavior: the case of the treefrog Bokermannohyla alvarengai (Bokermann, 1956). J Morphol 276: $1172-1182$

Christian KA, Tracy CR (1981) The effect of the thermal environment on the ability of hatchling Galapagos land iguanas to avoid predation during dispersal. Oecologia 49:218-223

CITES (2016) Convention on International Trade in Endangered Species of Wild Fauna and Flora: additional information on international trade: Telmatobius culeus.

https://cites.org/sites/default/files/eng/cop/17/InfDocs/ECoP17-Inf-71.pdf (accessed 23 Dec 2017)

Cossel J Jr, Lindquist E, Craig H, Luthman K (2014) Pathogenic fungus Batrachochytrium dendrobatidis in marbled water frog Telmatobius marmoratus: first record from Lake Titicaca, Bolivia. Dis Aquat Org 112:83-87

De la Riva I (2005) Bolivian frogs of the genus Telmatobius (Anura: Leptodactylidae): synopsis, taxonomic comments, and description of a new species. Monogr Herpetol 7: 65-101

De la Riva I, Lavilla EO (2008) Conservation status of the Andean frogs of the genera Telmatobius and Batrachophrynus. In: Stuart SN, Hoffmann M, Chanson J, Cox N, Berridge R, Ramani P, Young B (eds) Threatened amphibians of the world. Lynx Edicions, Barcelona, p 101

We la Riva I, Reichle S (2014) Diversity and conservation of the amphibians of Bolivia. Herpetol Monogr 28:46-65

Dejoux C (1991) El Lago Titicaca. In: Dejoux C Iltis A (eds) El Lago Titicaca: síntesis del conocimiento limnológico actual. Proyecto ORSTOM, Talleres Gráficos HISBOL, La Paz

*Daarte H, Tejedo M, Katzenberger M, Marangoni F, Baldo D, Beltrán JF, Gonzalez Voyer A (2012) Can amphibians take the heat? Vulnerability to climate warming in subtropical and temperate larval amphibian communities. Glob Change Biol 18:412-421

*Erskine DJ, Spotila JR (1977) Heat-energy-budget analysis and heat transfer in the largemouth blackbass (Micropterus salmoides). Physiol Zool 50:157-169

Flores V (2013) Preferencia de hábitat y densidad de Telmatobius culeus (Familia: Ceratophryidae) en el Lago Titicaca. BSc thesis, Universidad Mayor de San Andrés, La Paz

Fuentes A (2014) Elaboración de una para el manejo y control de aguas para la cría en cautiverio de Telmatobius culeus. Proyecto de grado en Ingeniería Ambiental. Universidad Catolica Boliviana San Pablo, Cochabamba

GBIF Secretariat (2017) GBIF backbone taxonomy. Checklist dataset. www.gbif.org/dataset/d7dddbf4-2cf0-4f399b2a-bb099caae36c (accessed 2 Jan 2018)

Geda F, Rekecki A, Decostere A, Bossier P, Wuyts B, Kalmar ID, Janssens GPJ (2012) Changes in intestinal morphology and amino acid catabolism in common carp at mildly elevated temperature as affected by dietary mannanoligosaccharides. Anim Feed Sci Technol 178:95-102 
Genova MI (2011) Density and habitat preferences of Lake Titicaca frog (Telmatobius culeus) at northwest of Copacabana peninsula. MSc thesis, Wageningen Universiteit

Häder DP, Williamson CE, Wängberg SÅ, Rautio M and others (2015) Effects of UV radiation on aquatic ecosystems and interactions with other environmental factors. Photochem Photobiol Sci 14:108-126

Hillman SS, Withers PC, Drewes RC, Hillyard SD (2009) Ecological and environmental physiology of amphibians. Oxford University Press, New York, NY

Homyack JA, Haas CA, Hopkins WA (2010) Influence of temperature and body mass on standard metabolic rate of eastern red-backed salamanders (Plethodon cinereus). J Therm Biol 35:143-146

Huey RB (1982) Temperature, physiology, and the ecology of reptiles. In: Biology of the Reptilia, Vol 12. Academic Press, New York, NY, p 25-91

*Huey RB, Slatkin M (1976) Cost and benefits of lizard thermoregulation. Q Rev Biol 51:363-384

Hutchison VH (1982) Physiological ecology of the Telmatobiid frogs of Lake Titicaca. Nat Geogr Soc Res Rep 14: 357-361

Hutchison VH, Haines HB, Engbretson G (1976) Aquatic life at high altitude: respiratory adaptations in the Lake Titicaca frog, Telmatobius culeus. Respir Physiol 27:115-129

Ibisch PL, Mérida G (2003) Biodiversidad: la riqueza de Bolivia Estado de conocimiento y conservación. Ministerio de Desarrollo Sostenible Editorial FAN, Santa Cruz de la Sierra-Bolivia

Icochea J, Reichle S, De la Riva I, Sinsch U, Köhler J (2004) Telmatobius culeus. The IUCN Red List of Threatened Species 2004:eT57334A11623098. http://dx.doi.org/102305/ IUCN.UK2004.RLTS.T57334A11623098.en (accessed 04 Jan 2017)

Jarvis A, Reuter HI, Nelson A, Guevara E (2008) Hole-filled seamless SRTM data V4. International Centre for Tropical Agriculture (CIAT). http://srtm.csi.cgiar.org/ (accessed 17 Feb 2017)

Kristín P, Gvoždík L (2014) Individual variation in amphibian metabolic rates during overwintering: implications for a warming world. J Zool (Lond) 294:99-103

Lansdown RV (2016) Zannichellia palustris. The IUCN Red List of Threatened Species 2016:e.T164133A96575438 http://dx.doi.org/10.2305/IUCN.UK.2016-1.RLTS.T164133 A96575438.en (accessed 30 Jan 2018)

Lavilla EO, Barrionuevo JS (2005) El género Telmatobius en la República Argentina: una síntesis. Monogr Herpetol 7: 115-165

Litzgus JD, Bolton F, Schulte-Hostedde AI (2008) Reproductive output depends on body condition in spotted turtles (Clemmys guttata). Copeia 86-92

MacLaughlin JA, Anderson RR, Holick MF (1982) Spectral character of sunlight modulates photosynthesis of previtamin D3 and its photoisomers in human skin. Science 216:1001-1003

Maniero GD, Carey C (1997) Changes in selected aspects of immune function in the leopard frog, Rana pipiens, associated with exposure to cold. J Comp Physiol B 167: 256-263

Molina CI, Lazzaro X, Guédron S, Achá D (2017) Contaminación de la Bahía de Cohana, Lago Titicaca (Bolivia):

Editorial responsibility: Michael Mahony,

Callaghan, New South Wales, Australia desafíos y oportunidades para promover su recuperación. Ecol Boliv 52:65-76

Navas CA (1997) Thermal extremes at high elevations in the Andes: physiological ecology of frogs. J Therm Biol 22: 467-477

Navas CA, Gomes FR, Carvalho JE (2008) Thermal relationships and exercise physiology in anuran amphibians: integration and evolutionary implications. Comp Biochem Physiol A Mol Integr Physiol 151:344-362

* Navas CA, Carvajalino Fernández JM, Saboyá Acosta LP, Rueda Solano LA, Carvajalino Fernández MA (2013) The body temperature of active amphibians along a tropical elevation gradient: patterns of mean and variance and inference from environmental data. Funct Ecol 27: 1145-1154

Perez ME (1998) Dieta y ciclo gametogénico anual de Telmatobius culeus (Anura: Leptodactylidae) en el Lago Titicaca (Huiñaimarca). BSc thesis, Universidad Mayor de San Andrés, La Paz

* Pizzatto L, Child T, Shine R (2008) Why be diurnal? Shifts in activity time enable young cane toads to evade cannibalistic conspecifics. Behav Ecol 19:990-997

Kaffel TR, Rohr JR, Kiesecker JM, Hudson PJ (2006) Negative effects of changing temperature on amphibian immunity under field conditions. Funct Ecol 20:819-828

Rojas S, Richards K, Jancovich JK, Davidson EW (2005) Influence of temperature on Ranavirus infection in larval salamanders Ambystoma tigrinum. Dis Aquat Org 63: 95-100

Rome LC, Stevens ED, John-Alder HB (1992) The influence of temperature and thermal acclimation on physiological function. In: Feder ME, Burggren WW (eds) Environmental physiology of the amphibians. University of Chicago Press, Chicago, IL, p 205

Seimon TA, Seimon A, Yager K, Reider K and others (2017) Long-term monitoring of tropical alpine habitat change, Andean anurans, and chytrid fungus in the Cordillera Vilcanota, Peru: results from a decade of study. Ecol Evol $7: 1527-1540$

* Sommaruga R, Psenner R (1997) Ultraviolet radiation in a high mountain lake of the Austrian Alps: air and underwater measurements. Photochem Photobiol 65:957-963

Wake DB, Vredenburg VT (2008) Are we in the midst of the sixth mass extinction? A view from the world of amphibians. Proc Natl Acad Sci USA 105:11466-11473

Wells KD (2007) The ecology and behaviour of amphibians. University of Chicago Press, Chicago, IL

Willaert B, Reichle S, Stegen G, Martel A, Lavayen SB, de Lozada NS, Muñoz-Saravia A (2016) Distribution, ecology, and conservation of the critically endangered frog Psychrophrynella illimani (Anura, Craugastoridae) with the description of its call. Salamandra (Frankf) 52:317-327

*Wilson RS, James RS, Johnston IA (2000) Thermal acclimation of locomotor performance in tadpoles and adults of the aquatic frog Xenopus laevis. J Comp Physiol B 170: $117-124$

Wright KM, Whitaker BR (2001) Amphibian medicine and captive husbandry Krieger Publishing, Malabar, FL

Z Zevallos S, Elías RK, Berenguel RA, Weaver TJ, Reading RP (2016) Batrachochytrium dendrobatidis in confiscated Telmatobius in Lima, Peru. J Wildl Dis 52:949-952

Submitted: October 4, 2017; Accepted: May 23, 2018

Proofs received from author(s): August 16, 2018 